\title{
Light-chain-induced renal tubular acidosis: effect of sodium bicarbonate on sodium-proton exchange
}

\author{
H. P. Reusch ${ }^{1}$, J. F. E. Mann ${ }^{1}$, M. J. Mihatch ${ }^{2}$, W. Siffert ${ }^{3}$ and F. C. Luft ${ }^{1,4}$ \\ ${ }^{1}$ Department of Internal Medicine-Nephrology University of Erlangen-Nürnberg, Germany; ${ }^{2}$ Institute for Pathology, \\ University of Basel, Switzerland; ${ }^{3}$ Max Planck Institute for Biophysics Frankfurt a.M., Germany; ${ }^{4}$ Franz Volhard Clinic, \\ Rudolf Virchow Univ. Hosps. Max Delbrück Center for Molecular Medicine, Free University of Berlin, Berlin, Germany.
}

\begin{abstract}
We measured sodium-proton $\left(\mathrm{Na}^{+} / \mathrm{H}^{+}\right)$ exchange in lymphocytes and platelets of a 46-yearold woman with the adult Fanconi syndrome before, during, and after treatment with $\mathrm{NaHCO}_{3}$. Kappa light chains in her urine and unique but rarely observed crystalline structures confirmed the presence of lightchain nephropathy. Her glomerular filtration rate was only moderately impaired at $72 \mathrm{ml} / \mathrm{min} . \mathrm{NaHCO}_{3}$ at 1,3 , and $5 \mathrm{mmol} / \mathrm{kg} /$ day for 5 days increased her serum $\mathrm{HCO}_{3}$ and $\mathrm{pH}$ from 17 to $21 \mathrm{mmol} / \mathrm{l}$ and 7.28 to 7.39 respectively. Plasma renin and aldosterone values were decreased by $\mathrm{NaHCO}_{3} \cdot \mathrm{Na}^{+} / \mathrm{H}^{+}$exchange $\left(\delta \mathrm{H}_{\mathrm{i}} / \mathrm{min}\right)$ was measured with the fluorescent marker BCECF after acidification of lymphocytes and platelets with sodium propionate at five $(10-50 \mathrm{mM})$ doses. $\mathrm{Na}^{+} / \mathrm{H}^{+}$exchange was accelerated in this patient compared to normal controls. $\mathrm{NaHCO}_{3}$ treatment significantly decreased $\mathrm{Na}^{+} / \mathrm{H}^{+}$exchange in lymphocytes, but not in platelets. These findings suggest that $\mathrm{Na}^{+} / \mathrm{H}^{+}$exchange can be influenced by $\mathrm{NaHCO}_{3}$ ingestion at doses that only modestly affect systemic $\mathrm{pH}$. Since $\mathrm{Na}^{+} / \mathrm{H}^{+}$exchange is involved in stimulus response coupling, cell growth regulation, cell differentiation, and perhaps the progression of nephrosclerosis, these observations may have clinical relevance.
\end{abstract}

Key words: renal tubular acidosis; Fanconi syndrome; Bence Jones protein; light chain nephropathy; sodiumproton exchange; sodium bicarbonate; multiple myeloma; electron-microscopy

\section{Introduction}

Renal Fanconi syndrome in adults is an uncommon cause of proximal renal tubular acidosis and is generally associated with multiple myeloma, light-chain proteinuria, or amyloidosis $[1,2]$. We were recently referred

Correspondence and offprint requests to: Friedrich C. Luft, MD, Franz Volhard Clinic, Univ. Hosps. Rudolf Virchow, Wiltberg Strasse 50, 13122 Berlin, Germany. an asymptomatic woman in whom glycosuria and proteinuria had been serendipitously identified. Elevated amounts of kappa light chains in her urine and multiple electron-dense, cytoplasmic, crystalline inclusions on renal biopsy secured the diagnosis. Sodium bicarbonate $\left(\mathrm{NaHCO}_{3}\right)$ loading, up to $5 \mathrm{mmol} / \mathrm{kg} /$ day, caused only a modest increase in her plasma $\mathrm{pH}$ and plasma $\mathrm{HCO}_{3}$ concentrations; however, it did decrease the accelerated sodium-proton $\left(\mathrm{Na}^{+} / \mathrm{H}^{+}\right)$exchange in her lymphocytes. This patient allowed us to corroborate our earlier observations, that $\mathrm{Na}^{+} / \mathrm{H}^{+}$exchange in lymphocytes is increased in patients with renal acidosis compared to values at a more normal systemic $\mathrm{pH}$ [3]. We now present evidence that $\mathrm{Na}^{+} / \mathrm{H}^{+}$exchange can be influenced by clinically attainable alkalinization.

\section{Subjects and methods}

\section{Case Report}

A 46-year-old woman was referred because of glycosuria and proteinuria on routine urinalysis. She denied any symptoms or lack of wellbeing. There was no family history of hypertension, renal disease, diabetes, or malignancy. She weighed $59 \mathrm{~kg}$, was $161 \mathrm{~cm}$ tall, and had a blood pressure of $140 / 85 \mathrm{mmHg}$. The rest of her physical examination was entirely normal. The haemoglobin was $14.4 \mathrm{~g} / \mathrm{dl}$, haematocrit $44 \mathrm{vol} \%$, white blood cell count 6800 , and platelet count $247,000 / \mathrm{mm}^{3}$. Tests of liver function and thyroid function were completely normal. Serologies for collagenoses and tests for cryoglobulins were negative. Multiple blood sugar values and an oral glucose tolerance test were normal. The sodium was $139 \mathrm{mmol} / \mathrm{l}$, chloride $111 \mathrm{mmol} / \mathrm{l}$, potassium $4.2 \mathrm{mmol} / \mathrm{l}$, calcium $2.26 \mathrm{mmol} / \mathrm{l}$, and phosphate $0.7 \mathrm{mmol} / 1$. The blood urea nitrogen was $32 \mathrm{mg} / \mathrm{dl}$, and uric acid concentration was $1.1 \mathrm{mg} / \mathrm{dl}$. An arterial blood sample disclosed a plasma $\mathrm{pH}$ of $7.35, \mathrm{PO}_{2} 100 \mathrm{mmHg}, \mathrm{PCO}_{2} 33 \mathrm{mmHg}$, and plasma $\mathrm{HCO}_{3} 18 \mathrm{mmol} / \mathrm{l}$. The serum protein electrophoresis disclosed only a marginal decrease in 
gammaglobulins. Plasma vitamin $\mathrm{D}_{3}$ values, plasma parathyroid hormone, plasma renin activity, and plasma aldosterone were within normal limits.

Roentgenograms of the thorax, axial skeleton and hands were unremarkable. An ultrasound examination showed kidneys which were normal in size and consistency. No abnormal calcifications or calculi were found. The plasma creatinine was $1.27 \mathrm{mg} / \mathrm{dl}$, creatinine clearance $76 \mathrm{ml} / \mathrm{min}, 24-\mathrm{h}$ urine protein excretion ranged between 2.3 and $3.8 \mathrm{~g} /$ day. The urinalysis revealed ++ proteinuria and $t+$ glycosuria. Granular casts were identified in the urinary sediment. A urine disc protein electrophoresis showed a mixed, tubular pattern. The urinary excretion of amino acids was generally increased with values for individual amino acids 4-10 times above the normal range. A fourfold increase in the normal urinary excretion of $\beta_{2}$ microglobulin was found. Urinary immunoelectrophoresis disclosed the presence of kappa light chains. A percutaneous renal biopsy and bone marrow biopsy were performed. The patient consented to a bicarbonate loading test after the University of Erlangen committee on human subjects had given approval. The protocol consisted of observation for 5 days, ingestion of $1 \mathrm{mmol} / \mathrm{kg}$, $3 \mathrm{mmol} / \mathrm{kg}$, and $5 \mathrm{mmol} / \mathrm{kg} \mathrm{NaHCO}$ daily each for 5 days, and an additional 10 -day recovery period. On the last day of each period, 24-h urine samples were collected. Arterialized venous blood was obtained for electrolytes, $\mathrm{pH}, \mathrm{PCO}_{2}, \mathrm{HCO}_{3}$, and $\mathrm{Na}^{+} / \mathrm{H}^{+}$exchange in lymphocytes and platelets three times during the baseline phase, at the end of each treatment phase, and twice during the recovery phase.

\section{Histology}

Renal tissue was obtained for light- and electronmicroscopy. A bone marrow biopsy was also obtained. The tissue preparation was done according to standard techniques. The material for light microscopy was fixed in $4 \%$ buffered formalin, embedded in paraplast, cut in 3- $\mu \mathrm{m}$-thick sections and stained with haematoxylin, PAS, PASM, and trichrome stains. The material for electron-microscopy was fixed in 3\% buffered glutaraldehyde, embedded in Epon and ultrathin sections were stained with lead citrate and uranyl acetate, and evaluated with a Phillips EM 200. Snap-frozen tissue was used for immunofluorescence.

\section{Preparation of platelet-rich plasma and isolation of lymphocytes}

The blood was anticoagulated by the addition of $20 \%$ (vol/vol) of acid citrate dextrose [3]. Platelet-rich plasma was prepared by centrifugation of blood at $200 \mathrm{~g}$ for $15 \mathrm{~min}$ at room temperature. The upper twothirds of the supernatant was used for the preparation of 2'-7'-bis (carboxyethyl) 5,6-carboxyfluorescein (BCECF)-loaded platelets and the remaining pellet was resuspended 1:1 with Hepes-buffered RPMI 1640 medium, $\mathrm{pH}$ 7.4. Lymphocytes were prepared after centrifugation of blood on a Ficoll gradient.

\section{Measurement of $p H_{i}$}

Cytosolic $\mathrm{pH}$ was determined using the fluorescent $\mathrm{pH}$ indicator BCECF. Pelleted platelets were resuspended in Hepes buffer consisting of $140 \mathrm{mM} \mathrm{NaCl}, 5 \mathrm{mM}$ $\mathrm{KCI}, 5 \mathrm{mM} \mathrm{KH} \mathrm{PO}_{4}, 1 \mathrm{mM} \mathrm{MgSO}, 10 \mathrm{mM}$ Hepes (free acid), and $5 \mathrm{mM}$ glucose, pH 6.5 (at $37^{\circ} \mathrm{C}$ ). $10 \mu \mathrm{M}$ BCECF-AM (final concentration; Molecular Probes Inc., Eugene, OR) was added, and the cells were incubated for $30 \mathrm{~min}$ at $37^{\circ} \mathrm{C}$. Thereafter, $1 \mu \mathrm{M}$ $\mathrm{PGI}_{2}$ was added and the cells were washed twice in Hepes buffer, pH 6.5, by repeated centrifugation. The final platelet pellet was resuspended in Hepes buffer,

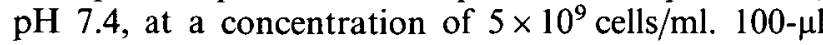
aliquots of these suspensions were transferred to $2 \mathrm{ml}$ of Hepes buffer in a cuvette and prewarmed at $37^{\circ} \mathrm{C}$. All measurements were conducted within $1 \mathrm{~h}$ after loading. During this time leakage of BCECF did not exceed $10 \%$ as assessed by comparison of fluorescence of platelets and corresponding supernatants and was, therefore neglected.

Lymphocytes and platelets were incubated with $10 \mu \mathrm{M}$ BCECF-AM for $30 \mathrm{~min}$ at $37^{\circ} \mathrm{C}$ in RPMI 1640 medium and washed twice in this medium by repeated centrifugation. Before prewarming to $37^{\circ} \mathrm{C}$, aliquots of lymphocytes were briefly spun down in an Eppendorf centrifuge and then resuspended into Hepes buffer before being used for fluorescence measurements (final concentration $1 \times 10^{3}$ cells $/ \mu \mathrm{l}$ ). This procedure efficiently removes extraneous dye. Leakage of dye during prewarming was $<10 \%$ and was therefore not corrected. The fluorescence of BCECF was recorded under constant stirring using a KONTRON SFM 24 spectrofluorimeter (Kontron, Düsseldorf, FRG) equipped with a thermostatted cuvette holder. Wavelengths for excitation and emission were set to 495 and $530 \mathrm{~nm}$ respectively. Calibration of the BCECF signals in terms of $\mathrm{pH}_{\mathrm{i}}$ was performed using the $\mathrm{K}^{+} /$nigericin method [3].

\section{Determination of $\mathrm{Na}^{+} / \mathrm{H}^{+}$exchange activity}

$\mathrm{Na}^{+} / \mathrm{H}^{+}$exchange was activated by addition of various amounts of $\mathrm{Na}^{+}$-propionate (final concentrations 10-50 mM) from a 1-M stock solution, $\mathrm{pH} 7.4$ [3]. Recovery of $\mathrm{pH}_{\mathrm{i}}$ in lymphocytes and platelets was inhibited by $>90 \%$ at $10 \mu \mathrm{M}$ of the specific inhibitor 5-(N-ethyl-N-isopropyl)-amiloride. Both findings suggest that $\mathrm{pH}_{\mathrm{i}}$ recovery was almost exclusively mediated by $\mathrm{Na}^{+} / \mathrm{H}^{+}$exchange. Osmotic activation of the antiport by $50 \mathrm{mM} \mathrm{NaCl}$ failed to affect $\mathrm{pH}_{\mathrm{i}}$ (data not shown). Initial rates of EIPA-sensitive $\mathrm{pH}_{\mathrm{i}}$ recovery were calculated as described in detail [3] and are expressed as $\delta \mathrm{pH}_{\mathrm{i}} / \mathrm{min}$. The relationship between $\mathrm{pH}_{\mathrm{i}}$ and $\mathrm{pH}_{\mathrm{i}}$ recovery could best be described by a sigmoidal function as stated earlier [3].

Exact characterization of the antiport's kinetic parameters can only be achieved by the nigericin $\mathrm{pH}_{\mathrm{i}}$ clamp method or by the $\mathrm{NH}_{4} \mathrm{Cl}$ prepulse method [3]. Determination of true $\mathrm{v}_{\operatorname{mqax}}$ requires acidification to $\mathrm{pH}_{\mathrm{i}}$ 6.0, whereas with propionate acidification beyond $\mathrm{pH}_{\mathrm{i}} 6.6$ (at $\mathrm{pH}_{\mathrm{o}}$ 7.4) cannot be achieved. Further, $\mathrm{pH}_{\mathrm{i}}$ 
recovery rates are dampened and the original baseline $\mathrm{pH}$ is not re-established due to the continuous influx of propionic acid. However, we wished to examine antiport activity in two cell specimens from one individual at the same occasion, which requires fast experimental procedures. This renders application of the nigericin $\mathrm{pH}_{\mathrm{i}}$ clamp method impossible, since this technique is time consuming. Further, prolonged storage of blood may affect antiport activity. Finally, neither the nigericin $\mathrm{pH}_{\mathrm{i}}$ clamp technique nor the $\mathrm{NH}_{4} \mathrm{Cl}$ prepulse method can be applied to platelets as these techniques require one or more centrifugation steps. In platelets this is possible only in the presence of agents that raise cAMP, or an acidic extracellular $\mathrm{pH}$, in order to prevent any preactivation or aggregation of these cells. Since these manipulations might have caused unforeseen effects on antiport activity, we preferred to use acidification by propionate, which enabled us to apply the same procedure to both cell types. Finally, all these potential confounders are present to a similar extent in all cell preparations under all conditions. This notion is also supported by the evaluation of the immediate effects of propionate addition on $\mathrm{pH}_{\mathbf{i}}$ in platelets and lymphocytes under the various states investigated. Identical amounts of $\mathrm{Na}^{+}$ propionate produced similar acidification of the cells (buffering capacity), whereas only $\mathrm{pH}_{\mathbf{i}}$ recovery rates were different (see results).

\section{Statistical analysis}

We conducted a repeated measures analysis of variance on the $\mathrm{Na}^{+} / \mathrm{H}^{+}$exchange data. Since each observation was derived from a different set of cells, the data could be analysed as independent observations. We tested for the $\partial \mathrm{pH}_{\mathrm{i}} / \mathrm{min}$ after each the five doses of propionate under control, under $\mathrm{HCO}_{3}$ administration, and under recovery conditions. We also compared the slopes of the relationships between $\partial \mathrm{pH}_{\mathrm{i}} / \mathrm{min}$ and $\mathrm{pH}_{\mathrm{i}}$. A $P$ value $<0.05$ was accepted as significant.

\section{Results}

\section{Renal biopsy}

The renal tissue for light-microscopy contained 12 normal glomeruli and two completely sclerosed glomeruli. The latter were surrounded by scattered lymphocytic infiltrates. The tubules were slightly dilated and the lumina did not contain casts. The proximal tubular epithelium exhibited minimal vacuolization (Figure 1). Crystalline structures were present within individual cells. No evidence of light-chain deposit disease, amyloidosis, or cast nephropathy was found. Immunofluorescence for immunoglobulins (IgG, IgM, IgA, complement factors C3 and C4 was negative. By electron-microscopy, the normal architecture of the glomeruli was confirmed. Proximal and distal tubules contained numerous highly osmiophilic protein crystals without suprastructure. These crystal- line structures were suggestive of light chains. Identical crystals were found in the bone marrow (Figure 2).

\section{$\mathrm{Na}^{+} / \mathrm{H}^{+}$exchange}

Plasma $\mathrm{Na}, \mathrm{Cl}$, and $\mathrm{K}$ barely changed while plasma $\mathrm{HCO}_{3}$ increased incrementally from 17 to $21 \mathrm{mmol} / \mathrm{l}$ and plasma $\mathrm{pH}$ increased incrementally from 7.28 to 7.39 with $\mathrm{NaHCO}_{3}$ loading. UNaV increased from 102 to $275 \mathrm{mmol} / 24 \mathrm{~h}$ at the highest dose of $\mathrm{NaHCO}_{3}$, while $\mathrm{UCl}$ and $\mathrm{K}$ excretion increased modestly. $\mathrm{Ca}$ excretion showed no consistent change. Urine $\mathrm{pH}$ increased from 6.1 at baseline to 8.3 at the highest dose of $\mathrm{NaHCO}_{3}$ and decreased to 5.7 thereafter. Plasma renin activity decreased from 2.95 to $0.84 \mathrm{ng} /$ Ang $\mathrm{I} / \mathrm{ml} / \mathrm{h}$, while plasma aldosterone decreased from 589 to $294 \mathrm{ng} / \mathrm{ml}$ with $\mathrm{NaHCO}_{3}$ loading.

In Figure 3 are shown $\mathrm{pH}_{\mathrm{i}}$ recovery rates in lymphocytes before (panel A), during (panel B), and after (panel C) $\mathrm{NaHCO}_{3}$ therapy. The lymphocytes obtained during $\mathrm{NaHCO}_{3}$ therapy displayed reduced $\mathrm{pH}_{\mathrm{i}}$ recovery rates after propionate; the $\delta \mathrm{pH}_{\mathrm{i}} / \mathrm{min}$ at each dose of propionate differed across treatments $(P<0.05)$ compared to values obtained before or after $\mathrm{NaHCO}_{3}$ therapy. The parameters from the data in Figure 3 yielded an apparent $\mathrm{v}_{\max }$ of $0.071 \delta \mathrm{pH}_{1} / \mathrm{min}$ before and $0.067 \delta \mathrm{pH}_{\mathrm{i}} / \mathrm{min}$ afterwards. During $\mathrm{NaHCO}_{3}$ therapy, on the other hand, the rate was reduced to $0.041 \delta \mathrm{pH}_{1} / \mathrm{min}$. The apparent halfmaximum activation occurred at $\mathrm{pH}_{\mathrm{i}} 6.9$ before, $\mathrm{pH}_{\mathrm{i}}$ 6.87 during, and $\mathrm{pH}_{\mathrm{i}} 6.85$ after the treatment. Thus the increase in apparent $v_{\max }$ in lymphocytes was not accompanied by an alkaline shift in the $\mathrm{Na}^{+} / \mathrm{H}^{+}$ exchanger activation curve. Moreover, the slope of the line generated by the relationship between $\delta \mathrm{pH}_{\mathrm{i}} / \mathrm{min}$ and $\mathrm{pH}_{\mathrm{i}}$ with $\mathrm{NaHCO}_{3}$ therapy differed from that obtained either before or after $\mathrm{NaHCO}_{3}$ treatment $(\mathrm{P}<0.05)$.

In contrast, no significant differences in $\mathrm{v}_{\max }$ were observed in the platelets (Figure 4). The parameters varied between $0.070 \delta \mathrm{pH}_{\mathrm{i}} /$ min before (panel A), 0.066 $\delta \mathrm{pH}_{\mathrm{i}} / \mathrm{min}$ during (panel $\mathrm{B}$ ) and $0.068 \delta \mathrm{pH}_{\mathrm{i}} / \mathrm{min}$ after (panel C) $\mathrm{NaHCO}_{3}$ treatment. The $\mathrm{pH}_{\mathrm{i}}$ values at which the apparent half-maximum activation of the antiporter occurred, varied only in a narrow range between 6.9 and 6.86 .

Finally, neither a change in basal $\mathrm{pH}_{\mathrm{i}}$ of the lymphocytes nor of the platelets was seen during the entire study. The values averaged $7.07 \pm 0.04,7.09 \times 0.05$, and $7.06 \pm 0.03$ for lymphocytes and $7.13 \pm 0.04$ $7.12 \pm 0.03$, and $7.14 \pm 0.01$ for platelets on day 0,15 and 25 respectively. In addition to the constant $\mathrm{pH}_{\mathrm{i}}$ values, enhancement of the lymphocyte antiport could not be attributed to changes in the buffering capacity for $\mathrm{H}^{+}$, since the addition of $50 \mathrm{mM}$ propionate caused the same degree of immediate acidification of the cells on all days $(0.043 \pm 0.04$ on day $0,0.045 \pm 0.09$ on day 15 (maximal $\mathrm{NaHCO}_{3}$ therapy) and $0.042 \pm 0.03$ after 10 days of recovery. Similar values were recorded for the platelets 


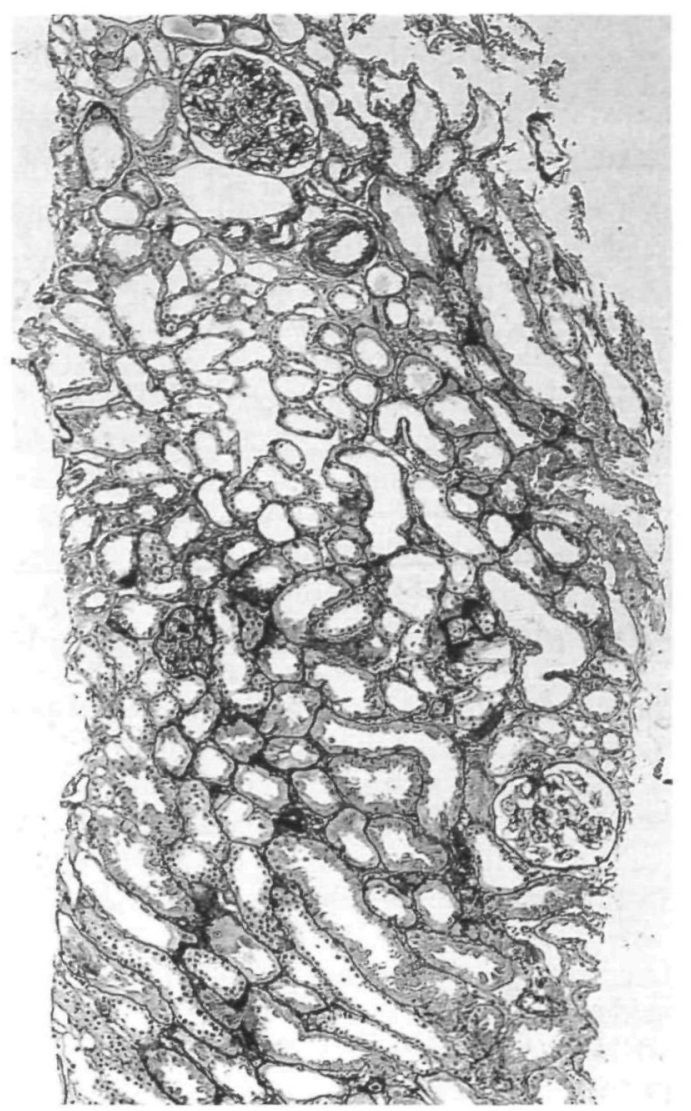

(a)

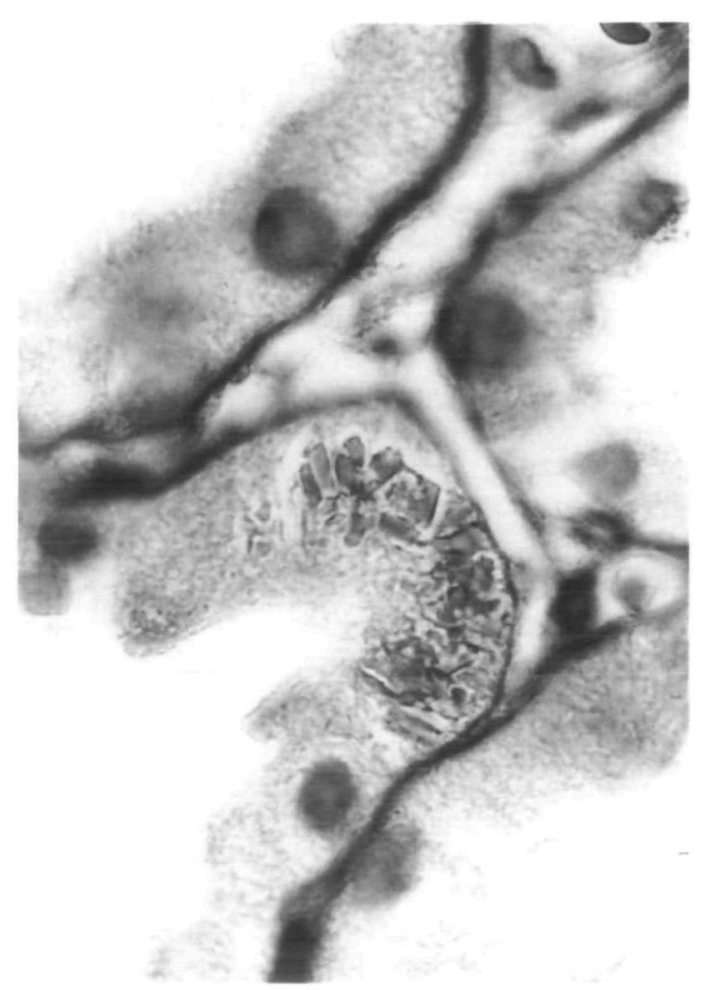

(c)

Fig. 1. Panel A shows an overview by lower power ( $\times 70$, PAS stain). Tubular dilatation is evident. Panels $\mathrm{B}, \mathrm{C}$, and $\mathrm{D}$ show individual tubules with crystalline structures $(\times 850)$. These were elucidated further by electron-microscopy.

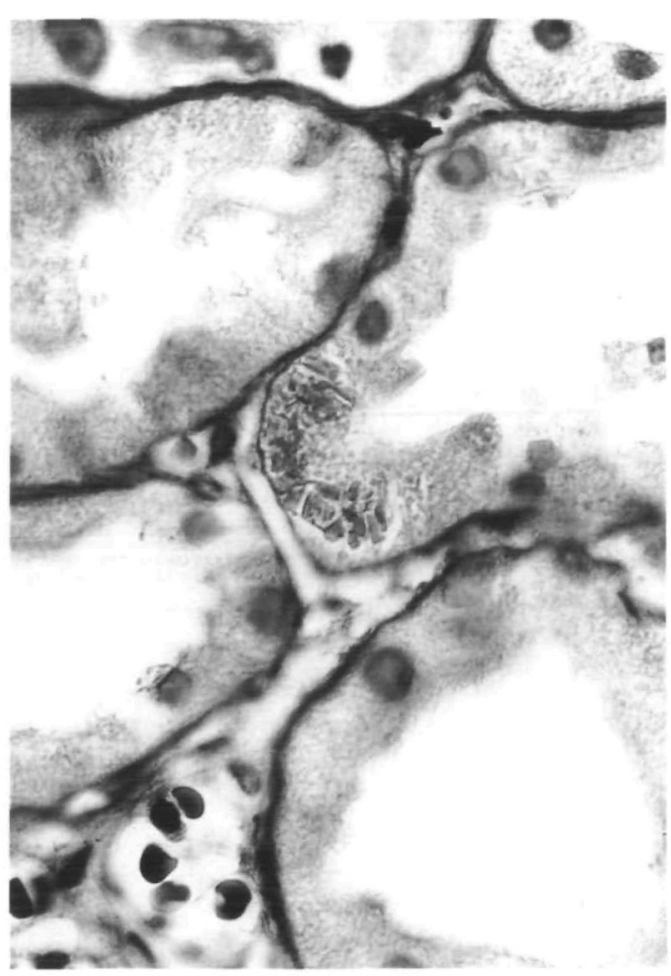

(b)

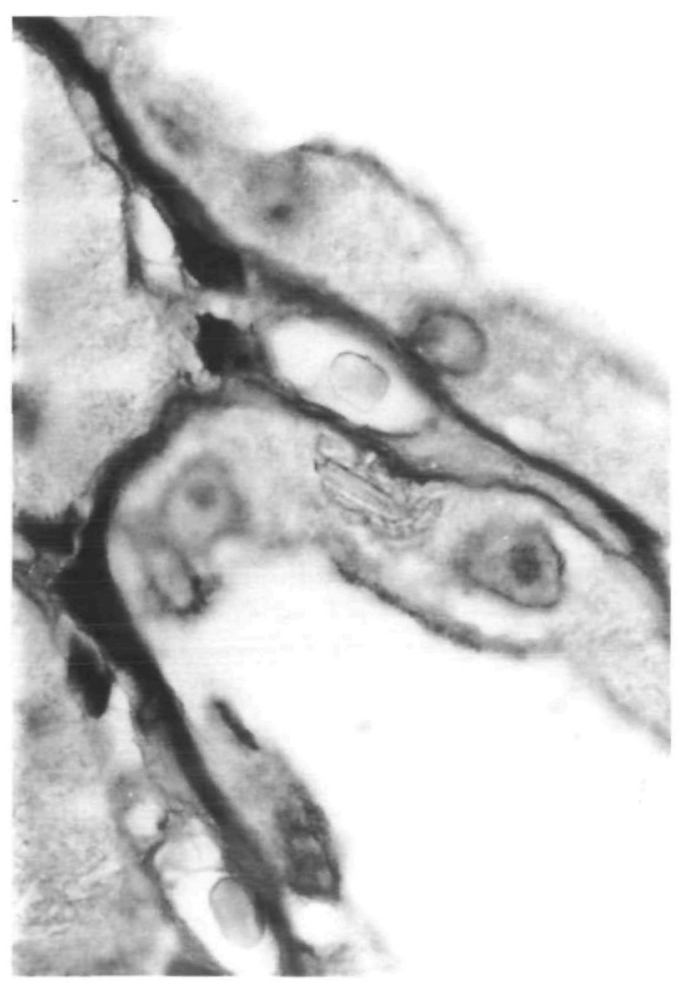

(d) 

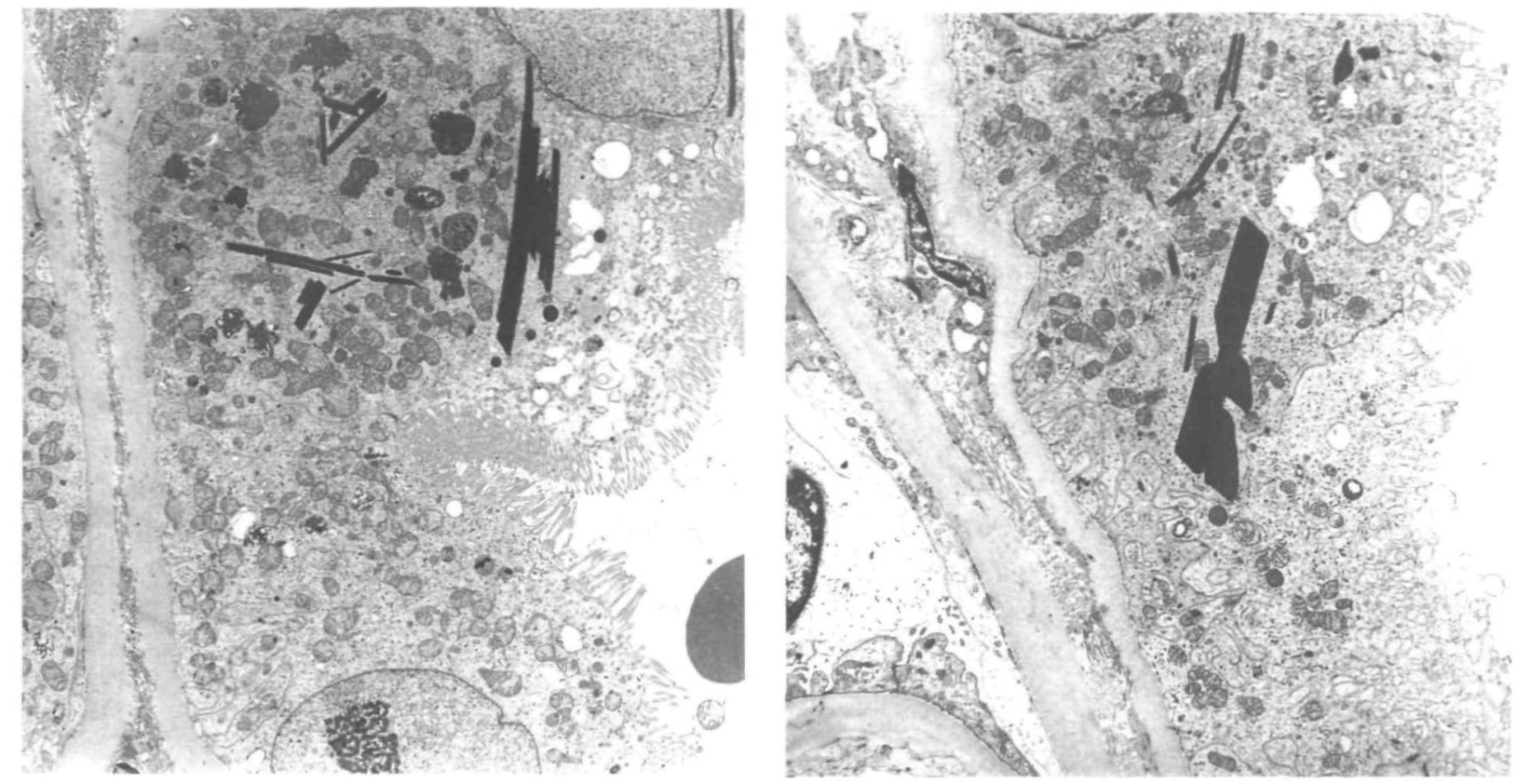

(a)

(b)
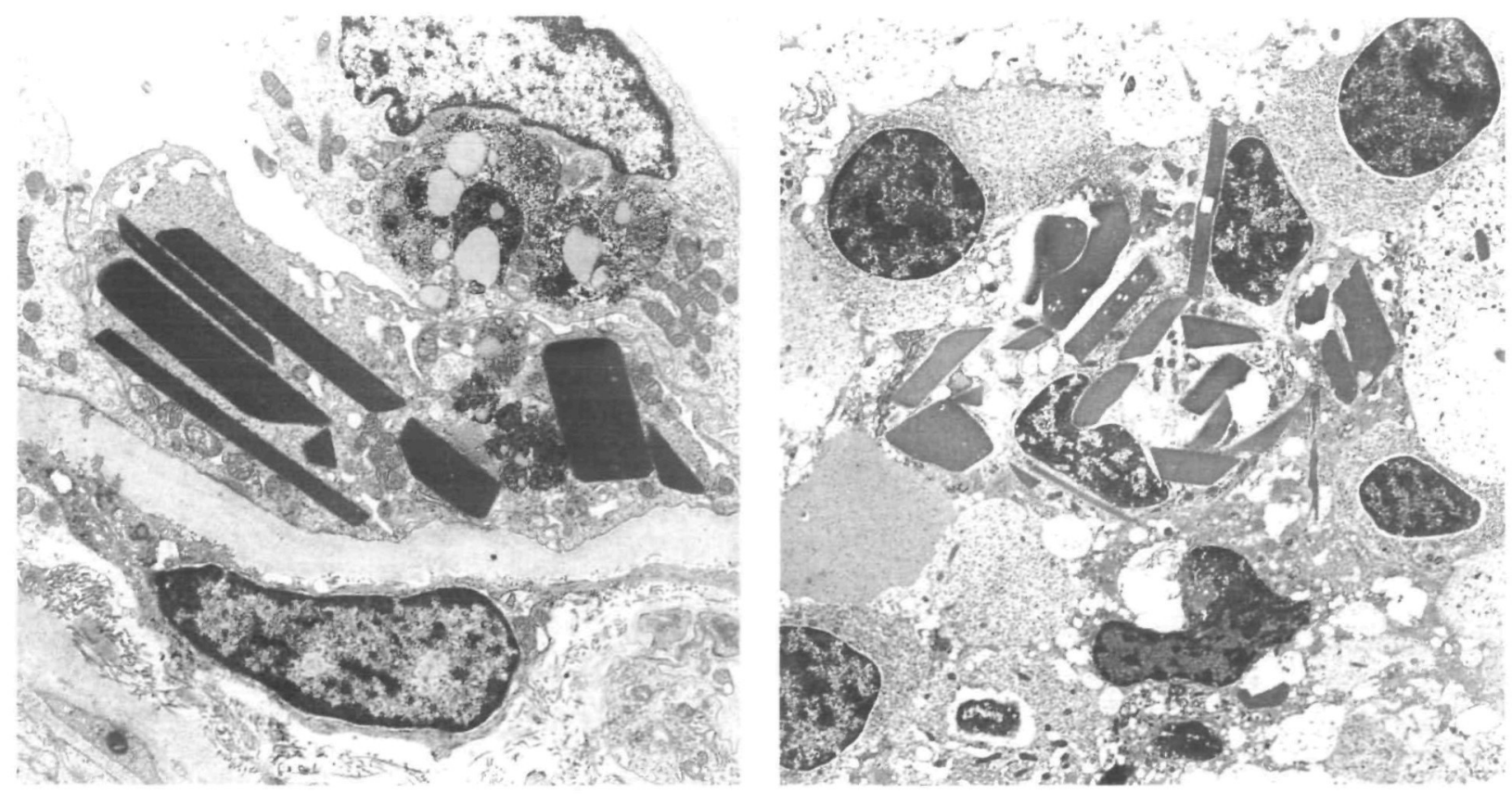

(c)

(d)

Fig. 2. Panels A, B, and C show the presence of protein crystals in tubular epithelial cells by transmission electron-microscopy. Panel D shows the presence of protein crystals in a specimen of bone marrow. The magnifications are $5 \times 957,5 \times 1305,5 \times 1972$, and $5 \times 957$ respectively.

\section{Discussion}

This patient presented with an unusual, but welldescribed proximal renal tubular acidosis resulting from the effects of deposited light chains [1,2]. She had all the clinical features of the adult Fanconi syndrome, as well as kappa light chains in her urine. The renal biopsy showed none of the typical renal complications of multiple myeloma, i.e. amyloidosis, cast nephropathy or light-chain deposit disease [9]. Rather, slight vacuolization of proximal tubular cells and intracellular osmiophilic crystals compatible with light chain crystals were found. Thus our patient is unusual. The overall incidence of crystals in kidneys of patients with plasma cell dyscrasia accounts for about $6 \%$; crystals in large amounts are found in only 

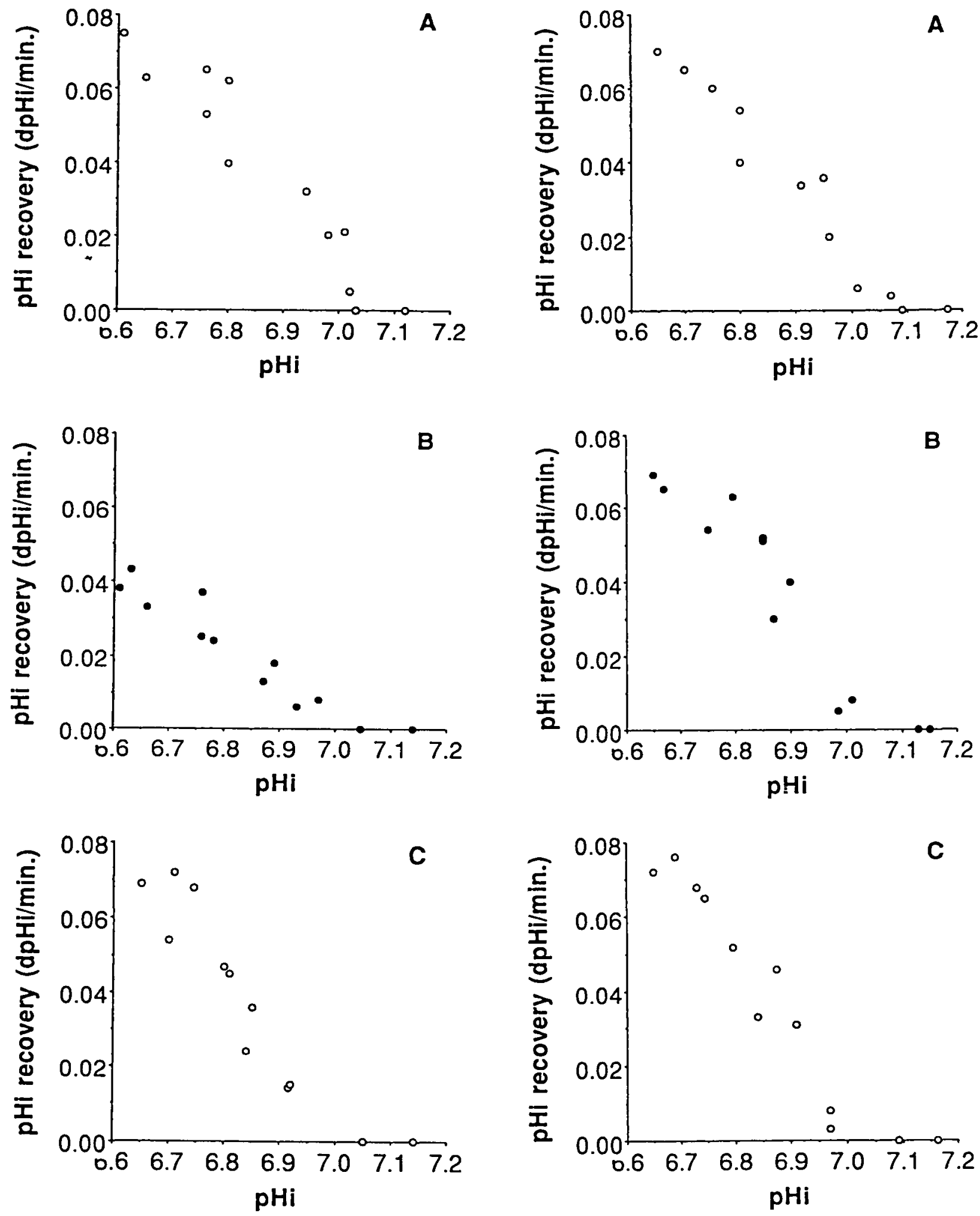

Fig. 3. The effect of $\mathrm{NaHCO}_{3}$ on $\mathrm{Na}^{+} / \mathrm{H}^{+}$exchange rates in lymphocytes. On the ordinate are shown the pooled $\mathrm{pH}_{1}$ recovery rates $\left(\partial \mathrm{pH}_{\mathrm{i}} / \mathrm{min}\right.$ ) during control (panel A), day 15 of $\mathrm{NaHCO}_{3}$ ingestion (panel B), and 10 days after $\mathrm{NaHCO}_{3}$ treatment (panel C). On the abscissa is shown then pHi values obtained by acidifying the cells

Fig. 4. The effect of $\mathrm{NaHCO}_{3}$ on $\mathrm{Na}^{+} / \mathrm{H}^{+}$exchange rates in platelets (see Figure 3). The slopes of the regression relationships are not different, indicating no effect of $\mathrm{NaHCO}_{3}$ treatment on $\mathrm{Na}^{+} / \mathrm{H}^{+}$ exchange rates in platelets. are different $(P<0.05)$; that in panel $\mathrm{B}$ after $\mathrm{NaHCO}$ treatment is flatter than before (A) or after (C) the treatment. 
$1 \%$ of cases. In cases of cast nephropathy, crystals in tubular casts and/or tubular epithelium were reported in 18 of 24 patients [10], and in eight of 12 patients with concomitant Fanconi's syndrome [1]. Cases of tubular vacuolization with intracytoplasmic crystals associated with Fanconi's syndrome without cast nephropathy are highly uncommon. To our knowledge only three cases were reported in the literature $[1,11,12]$. Two were associated with kappa chain $[1,11]$, one with lambda light-chain excretion [12]. We believe our light- and electron-photomicrographs of both bone marrow and renal tissue are an excellent example of this rare condition.

We administered $\mathrm{NaHCO}_{3}$ to our patient in order to document that the threshold for $\mathrm{HCO}_{3}$ was drastically reduced [13]. Our patient had difficulty tolerating the $5 \mathrm{mmol} / \mathrm{kg} /$ day dose because of gastrointestinal side-effects. We encountered urine $\mathrm{pH}$ values above 5.5. Thus it is quite possible that our patient also had some degree of distal tubular dysfunction. We failed to determine the $\mathrm{pCO}_{2}$ of her urine, which would admittedly have clarified matters.

$\mathrm{Na}^{+} / \mathrm{H}^{+}$exchange or antiport is important in regulation of $\mathrm{pH}_{\mathrm{i}}$, cell volume, stimulus response coupling, and cell proliferation [14]. The finding that $\mathrm{Na}^{+} / \mathrm{H}^{+}$ exchange is increased in hypertension and diabetes raises the possibility that $\mathrm{Na}^{+} / \mathrm{H}^{+}$exchange may be relevant to the pathogenesis of these conditions or their complications $[15,16]$. Since Nath et al. [17] showed that $\mathrm{NaHCO}_{3}$ treatment ameliorated the course of chronic renal failure in rats with $5 / 6$ nephrectomy, particularly in terms of reducing interstitial proliferative changes which may be related to ammonia production [18], it occurred to us that perhaps the acidosis of chronic renal disease is associated with accelerated $\mathrm{Na}^{+} / \mathrm{H}^{+}$exchange. In an earlier study [3], we observed such an increase in $\mathrm{Na}^{+} / \mathrm{H}^{+}$exchange in lymphocytes of patients with chronic renal disease compared to normal subjects as well as in normal subjects given $\mathrm{NH}_{4} \mathrm{Cl}$ for 5 days. Patients with chronic renal disease had a mean $\mathrm{pH}_{\mathrm{i}}$ recovery $(\delta \mathrm{pH} / \mathrm{min})$ of 0.08 (range $0.07-0.11$ ), compared to a mean 0.05 observed in normal subjects [3]. Our patient's $\delta \mathrm{pHi} / \mathrm{min}$ value was 0.08 . We were also able to show by means of quantitative, reverse transcription polymerase chain reaction [19] that NHE-1 mRNA was increased under the condition of metabolic acidosis, suggesting that additional antiporter protein was produced. A recent study of erythrocytes from patients with renal insufficiency supports this view [20].

The $\mathrm{Na}^{+} / \mathrm{H}^{+}$exchanger in lymphocytes and platelets is not identical with the $\mathrm{Na}^{+} / \mathrm{H}^{+}$exchanger present on renal tubular brush border epithelium. Krapf et al. studied the effects of metabolic acidosis induces on $\mathrm{Na}^{+} / \mathrm{H}^{+}$exchange in renal tissue and were able to show an increase in antiport mRNA in renal tubular cells $[21,22]$. Moe et al. $[8,23]$ were able to confirm that mouse renal cortical tubule cells and an opossum kidney cell line responded to a $24-\mathrm{h}$ in vitro metabolic acidosis with an almost twofold increase in $\mathrm{Na}^{+} / \mathrm{H}^{+}$ exchange activity. This increase in antiport activity was accompanied by a threefold increase in antiport mRNA. These results could be confirmed by feeding rats with a diet that induced metabolic acidosis. The increase in antiport activity could also be inhibited by the addition of cycloheximide to the culture medium. These findings could apply to $\mathrm{Na}^{+} / \mathrm{H}^{+}$exchange in lymphocytes and platelets.

If one accepts the hypothesis of an as yet unidentified $\mathrm{pH}_{\mathrm{i}}$-sensor in these cells, an effect on antiport mRNA and de-novo regulation of the corresponding protein synthesis in lymphocytes appears conceivable. Platelets, on the other hand, are non-nucleated 'cells' which have only a minor capability of protein synthesis, if any. It is possible that the relatively short-term $\mathrm{NaHCO}_{3}$ treatment was insufficient to assure adequate numbers of new circulating platelets with decreased antiport activity. Since we could only measure the overall platelet $\mathrm{Na}^{+} / \mathrm{H}^{+}$exchange activity, minor differences were most likely under the detection limits of our assay.

It is also possible that circulating agonists influenced $\mathrm{Na}^{+} / \mathrm{H}^{+}$exchange in the lymphocytes of our patient. Although her renin and aldosterone values were normal prior to the intervention, the administration of $\mathrm{NaHCO}_{3}$ had a suppressing effect on renin and aldosterone not dissimilar from that reported after sodium citrate by Sharma et al. [24]. Aldosterone enhances $\mathrm{Na}^{+} / \mathrm{H}^{+}$exchange activity in human lymphocytes in vitro [25-27]. Angiotensin is also able to stimulate $\mathrm{Na}^{+} / \mathrm{H}^{+}$exchange [28]. Thus we cannot rule out the possibility that the decrease in $\mathrm{Na}^{+} / \mathrm{H}^{+}$exchange we observed after $\mathrm{NaHCO}_{3}$ in lymphocytes was mediated by hormones instead of a direct $\mathrm{pH}$ effect.

It is possible that acidosis per se may be important in the progression of chronic renal disease. Protein degradation is enhanced and growth is impaired by acidosis in uraemia [29]. $\mathrm{Na}^{+} / \mathrm{H}^{+}$exchange may be involved in these effects. In contrast to our findings and those of Corry et al. [20], Greiber and Mitch found that the antiport was decreased in thymocytes of uraemic rats [30]. Additional studies will be necessary to elucidate these issues. Finally, the abovementioned findings by Nath et al. [17] have not received the attention they deserve. Although reduced protein intake is an accepted preventative strategy in chronic renal failure management, control of acidosis when applied at all is primarily conducted to prevent bone disease. We suggest that control of renal acidosis may be directly relevant to the progression of chronic renal disease, perhaps by influencing $\mathrm{Na}^{+} / \mathrm{H}^{+}$ exchange.

Acknowledgements. These studies were supported by grants in aid from the Verband, Deutscher Mineralbrunnen, Siemens Erben, and Sandoz AG.

\section{References}

1. Maldonado JE, Velosa JA, Kyle RA, Wagoner RD, Holley KE, Salassa RM. Fanconi syndrome in adults: a manifestation of a latent form of myeloma. Am J Med 1975; 58: 354-364

2. Smithline N, Kassirer JP, Cohen JJ. Light-chain nephropathy: 
renal tubular dysfunction associated with light-chain proteinuria. N Engl J Med 1976; 294: 71-74

3. Reusch HP, Reusch R, Rosskopf D, Siffert W, Mann JFE, Luft FC. $\mathrm{Na}^{+} / \mathrm{H}^{+}$exchange in human lymphocytes and platelets in chronic and subacute metabolic acidosis. J Clin Invest 1993; 92: $858-865$

4. Peper RJ, Tina WZ, Mickelson MM. Purification of lymphocytes and platelets by gradient centrifugation. J Lab Clin Med 1968; 72: $842-848$

5. Rink TJ, Tsien RY, Pozzan T. Cytoplasmic $\mathrm{pH}$ and free $\mathrm{Mg}$ in lymphocytes. J Cell Biol 1988; 95(1): 189-96

6. Siffert W, Siffert G, Scheid P, Akkerman JWN. $\mathrm{Na}^{+} / \mathrm{H}^{+}$ Exchange modulates Ca Mobilization in human platelets stimulated by ADP and the thromboxane mimetic U 46619. J Biol Chem 1990; 264: 719-725

7. Siffert W, Jakobs KH, Akkerman JWN. Sodium fluoride prevents receptor-and protein kinase $\mathrm{C}$-mediated activation of the human platelet $\mathrm{Na}^{+} / \mathrm{H}^{+}$exchanger without inhibiting its basic $\mathrm{pH}_{1}$-regulating activity. $J$ Biol Chem 1990; 265: 15441-15448

8. Moe OW, Miller RT, Horie S, Cano A, Preisig PA, Alpern RJ. Differential regulation of $\mathrm{Na}^{+} / \mathrm{H}^{+}$antiporter by acid in renal epithelial cells and fibroblasts. J Clin Invest 1991; 88: 1703-1708

9. Schubert GE. Die Plasmozystniere. I. Häufigkeit pathologischanatomischer Veränderungen. Klin Wochenschr 1974; 52: 763-770

10. Pirani CL, Silva F, D'Agatı V. Renal lesions in plasma cell dyscrasia: Ultrastructural observations. Am J Kidney Dis 1987; 10: $208-221$

11. Lee DBN, Drinkard JPD. The adult Fanconi syndrome: Observations on etiology, morphology, renal function and mineral metabolism in three patients. Medicine 1972; 51: 107-124

12. Thorner PS, Bedard YC, Fernandes BJ. Lambda-light-chain nephropathy with Fanconi's syndrome. Arch Pathol Lab Med 1983; 107: 654-657

13. Kurtzman NA. Acquired distal renal tubular acidosis. Kidney Int 1983; 24: 807-819

14. Seifter JL, Aronson PS. Properties and physiological roles of the plasma membrane sodium-hydrogen exchanger. $J$ Clin Invest 1986; 78: 859-864

15. Rosskopf $\mathrm{D}$, Düsing $\mathrm{R}$, Siffert $\mathrm{W}$. Membrane $\mathrm{Na} / \mathrm{H}$ exchange and primary hypertension. Hypertension, (in press)

16. Huot SJ, Aronson PS. Na-H exchanger and its role in essential hypertension and diabetes mellitus. Diabetes Care 1991; 14: 521-535

17. Nath KA, Hostetter MK. Hostetter TH. Pathophysiology of chronic tubulo-interstitial disease in rats. Interactions of dietary acid load, ammonia and complement component C3. J Clin Invest 1985; 76: 667-675

18. Tolins JP, Hostetter MK, Hostetter TH. Hypokalemic nephropathy in the rat: role of ammonia in chronic tubular injury. J Clin Invest 1987; 79: 1447-1458

19. Quednau B, Rosskopf D, Reusch HP, Luft FC, Siffert W. Enhanced $\mathrm{Na}^{+} / \mathrm{H}^{+}$-exchanger activity and raised $\mathrm{Na}^{+} / \mathrm{H}^{+}$exchanger mRNA levels in human lymphocytes during metabolic acidosis. Am J Physiol 1994; 266: C480-C488

20. Corry DB, Tuck ML, Nicholas S, Weinmann EJ. Increased $\mathrm{Na} / \mathrm{H}$ antiport activity and abundance in uremic red blood cells. Kidney Int 1993; 44: 574-578

21. Krapf R, Pearce D, Lynch C, Xi X-P, Reudelhuber TL, Pouyssegur J, Rector FC. Expression of rat renal $\mathrm{Na}^{+} / \mathrm{H}^{+}$ antiporter $\mathrm{mRNA}$ levels in response to respiratory and metabolic acidosis. $J$ Clin Invest 1991; 87: 747-751

22. Krapf R, Solioz M, Fehlmann C. $\mathrm{Na}^{+} / \mathrm{H}^{+}$antiporter mRNA expression in single nephron segments of rat kidney cortex. $J$ Clin Invest 1991; 88: 783-788

23. Horie S, Moe O, Tejedor A, Alpern RJ. Preincubation in acid medium increases $\mathrm{Na}+/ \mathrm{H}+$ antiporter activity in cultured renal proximal tubule cells. Proc Natl Acad Sci USA 1991; 87: $4742-4745$

24. Sharma AM, Schattenfroh S, Thiede HM, Oelkers W, Distler A. Effects of sodium salts on pressor reactivity in salt-sensitive men. Hypertension 1992; 19: 541-548

25. Wehling M, Käsmayr J, Theisen K. Rapid effects of mineralocorticoids on sodium-proton exchanger. Genomic or nongenomic pathway. Am J Physiol 1991; 260: E719-E726

26. Wehling M, Käsmayr J, Theisen K. Fast effects of aldosterone on electrolytes in human lymphocytes are mediated by the sodium-proton exchange of the cell membrane. Biochem Biophys Res Commun 1984; 164: 961-967

27. Wehling $\mathbf{M}$, Käsmayr $J$, Theisen $\mathrm{K}$. The $\mathrm{Na}-\mathrm{H}$ exchanger is stimulated and cell volume increased in lymphocytes from patients with essential hypertension. J Hypertens 1991; 9; 519-524

28. Saccomani G, Mitchell KD, Navar LG. Angiotensin II stimulation of $\mathrm{Na}-\mathrm{H}$ exchange in proximal tubular cells. Am $J$ Physiol 1990; 258: F1188-F1195

29. Maniar S, Laouri D, Caldas A, Kleinknecht C. Protein synthesis and growth in uremic rats with and without chronic metabolic acidosis. Miner Electrolyte Metab 1992; 18: 250-252

30. Greiber S, Mitch WE. Mechanisms for protein catabolism in uremia: metabolic acidosis and activation of proteolytic pathways. Miner Electrolyte Metab 1992; 18: 233-236 